\title{
PROTEIN SYNTHESIS IN NEURONS AND GLIAL CELLS OF THE DEVELOPING RAT BRAIN: AN IN VIVO STUDY ${ }^{1}$
}

\author{
D. E. JOHNSON ${ }^{2}$ and O. Z. SELlinger \\ Mental Health Research Institute, The University of Michigan Medical Center, \\ Ann Arbor, Michigan
}

(Received 20 October 1970. Accepted 8 January 1971)

\begin{abstract}
A technique for the isolation of pure neuronal perikarya and intact glial cells from cerebral cortex has been developed for routine use. The yield of neuronal perikarya and glial cells was greater from highly immature (5-10 days) rat cerebral cortex than from the cortex of older rats (18-43 days). The perikarya/glia yield ratio decreased with age indicating that, as the glial population matured, the procedure succeeded in isolating a gradually smaller proportion of the existing neurons. The perikarya/glia ratio was highest for the 5-dayold cortex in which no mature glial cells could be identified.

After a 10-min pulse in vivo of intrathecally injected $\left[{ }^{14} \mathrm{C}\right]$ phenylalanine, the specific radioactivity of the neuronal proteins was higher than that of the glial proteins in the 5-, 10- and 18-day-old rat but was lower in the 43-day-old rat. The values for absolute specific radioactivity of the ${ }^{14} \mathrm{C}$-labelled proteins in both cell types were greater, the younger the brain. The ${ }^{14} \mathrm{C}$-labelling of neuronal and glial proteins in the 18 -day-old rat was assessed in vivo as a function of time by determining the incorporation of $\left[{ }^{14} \mathrm{C}\right]$ phenylalanine into such proteins at 5,10,20 and $45 \mathrm{~min}$ after administration of the amino acid. The rate of incorporation of $\left[{ }^{14} \mathrm{C}\right]$ phenylalanine into the glial cells was faster than into the neurons since higher specific radioactivities of the glial proteins could be achieved at earlier times. Also, a biphasic pattern of ${ }^{14} \mathrm{C}$-labelling of the glial proteins was noted, suggesting, perhaps, a sequential involvement of the oligodendrocytes and astrocytes.

Homogenates of prelabelled neuronal perikarya were fractionated into the nuclear, mitochondrial, microsomal and soluble cell sap fractions. In the 18-day-old cerebral cortex, the proteins of the microsomal fraction exhibited the highest specific radioactivity at the end of $10 \mathrm{~min}$, whereas by $20 \mathrm{~min}$ proteins of the mitochondrial fraction were most highly labelled. The specific radioactivity of the nuclear proteins increased over the entire 45 -min experimental period. On the contrary, the proteins of the soluble cell sap, in which the specific radioactivity was at all times by far the lowest, were maximally labelled by $5 \mathrm{~min}$. Examination of the labelling of the neuronal subcellular fractions as a function of age revealed that at $10 \mathrm{~min}$ after administration of $\left[{ }^{14} \mathrm{C}\right]$ phenylalanine, the specific radioactivities of all ${ }^{14} \mathrm{C}$-labelled proteins were highest in the youngest (5-day-old) neurons. The proteins of the microsomal fraction were most rapidly labelled at all ages. During this interval the proteins of the soluble cell sap were only moderately labelled in the 5-day-old neurons and were totally unlabelled in the 43-day-old neurons, indicating age-dependent differences in the rate of utilization of the amino acid precursor by the neurons.
\end{abstract}

THE BRAIN is characterized by a high rate of protein synthesis (for reviews see LAJTHA, $1964 a, b)$. The rate of synthesis of cerebral proteins and of RNA is higher in the immature animal than in the adult (MILleR, 1969; ROBERTS, ZOMZELY and BONDY, 1970). BARONDES (1964) and YAMAGAMI, FRITZ and RAPPOPORT (1966) have shown that RNA polymerase and RNA are more active in brains of immature animals than in those of adults. Schain, Carver, Copenhaver and UNDerdahl (1967) examined the rate in vivo of incorporation of amino acids into pig brain and observed that the maximum

${ }^{1}$ This work was supported in part by training grant MH-07417 from the National Institute of Mental Health and grant no. NB 06294 from the United States Public Health Service.

2 Post-doctoral trainee.

Abbreviations used: BSA, bovine serum albumin; G, glial cells; NP, neuronal perikarya; PPO, 2,5 diphenyloxazole; dimethyl POPOP, 1,4 bis [2-(4-methyl-5-phenyloxazolyl)]-benzene; PVP, polyvinylpyrrolidone. 
decrease in protein synthesis occurred soon after birth and was later followed by a more gradual decline. ABDEL-LATIF and ABOOD (1966) studied the incorporation in vivo of $\left[{ }^{14} \mathrm{C}\right]$ serine into the subcellular fractions of the developing rat brain and found that the proteins of all fractions were more highly labelled in the immature brain than in the older brain. In general, the in vivo experiments have been confirmed by in vitro studies which show that the rates of protein and nucleic acid synthesis decrease in mammalian brain during development (LAHIRI and LAJTHA, 1964; MURTHY and RAPPOPORT, 1965; MURTHY, 1966; YAMAGAMI et al., 1966; AdAMS and LiM, 1966; JOHNSON and LUTTGES, 1966; JOHNSON, 1967, 1968; BONDY and ROBERTS, 1968; Johnson and BelytschKo, 1969; Yamagami and Mori, 1970).

In addition to the general pattern of decreasing protein synthesis with age, a marked change occurs in protein turnover which becomes progressively slower with age. Changes in the qualitative nature of the proteins also appear to relate to the development of brain tissue (GAITONDE and RICHTER, 1956; LAJTHA, FURST, GERSTEIN and WAELSCH, 1957; LAJTHA, 1964a; RoBerTs et al., 1970) and may thus reflect the physiological activity of particular brain cells which synthesize specific 'developmental' proteins such as the acidic S-100 protein (MoOre, Perez and GeHring, 1968; FriedMAN and WENGER, 1970), the basic protein associated with myelin (HERRIMAN and HuNTER, 1965) and microtubular protein (DUTTON and BARONDES, 1969; TUOMEY and WYTTENBACH, 1970). Brain tissue consists principally of neurons and glial cells, the relative proportions of which change markedly with the age of the brain. In a developmental study on rats ranging from 5 to 730 days of age, BRIzzeE, VOGT and KHARETCHKO (1964) found the glial population to be relatively small in the cerebral cortex of immature rats but to exceed by far that of the neurons in adult animals. Since virtually all previous studies on cerebral protein synthesis have utilized intact brain and thus perforce disregarded the problems of the changing proportions of, and of the quantitative differences between, neurons and glial cells known to characterize cerebral maturation, we thought it desirable to assess the synthetic contribution of the two cell types after their separation from one another.

Four distinct but only partially satisfactory procedures have been described for the separation of neurons from glial cells: (a) brain is treated with a mixture of acetoneglycerol and water prior to mincing and centrifugation (SATAKE and ABE, 1966; Satake, Hasegawa, Abe and Tanaka, 1968; Freysz, Bieth, Judes, Sensenbrenner, JACOB and MANDEL, 1968); (b) brain mince is sieved and subjected to gradient centrifugation (RoSe, 1967; ROSE and SinHA, 1969; BLOMSTRAND and HAMBERgER, 1969); (c) whole brain is disrupted in a tissue press and zonal centrifugation used to separate the cellular elements (FLANGAS and BowMAN, 1968) and (d) chopped brain is incubated under oxygen at $37^{\circ} \mathrm{C}$ in the presence of trypsin (NORTON and PODUsLo, 1970). An additional procedure has recently been developed in our laboratory which avoids some of the pitfalls of previous procedures and which makes it possible to isolate pure neuronal perikarya (NP) and intact glial cells (G) from as little as $1 \mathrm{~g}$ of cerebral cortex and in yields which permit the subsequent subcellular fractionation of the isolated cells (Sellinger and Azcurra, 1970; Sellinger, Azcurra, Johnson, OHLSSON and LODIN, 1971). Using this procedure, we have carried out an investigation of the time course in vivo of protein synthesis in the neurons and the glial cells of rat cerebral cortex during development. A preliminary account of some of the results has appeared (JOHNSON and SELLINGER, 1970). 


\section{MATERIALS AND METHODS}

Animals and materials. Sprague-Dawley, male rats of 5,10,18 and 43 days of postnatal age were used. L-[U- $\left.{ }^{14} \mathrm{C}\right] \mathrm{Ph}$ hylalanine with a specific activity of $>350 \mathrm{mCi} / \mathrm{mmol}$ was obtained from New England Nuclear Corp. (Boston, Mass.). Bovine serum albumin (BSA; fraction V) was obtained from Pentex Biochemicals (Kankakee, Ill.). Polyvinylpyrrolidone (PVP; Plasdone C, average mol. wt. 40,000) was purchased from GAF Corporation (Calvert City, Kentucky). Ficoll was obtained from Pharmacia (Uppsala, Sweden). Sucrose (special enzyme grade) was purchased from Mann Research Laboratories (New York, N.Y.). PPO and dimethyl POPOP were obtained from Packard Instruments (Downers Grove, Ill.). Biosolv No. 3 was purchased from Beckman Co. (Fullerton, Calif.). Glutaraldehyde $(70 \%, \mathrm{v} / \mathrm{v}$, solution sealed under nitrogen in $2 \mathrm{ml}$ ampoules) and Epon 812 were purchased from Ladd Research Industries (Burlington, Vermont). All other reagents were of the purest grade available. Millipore filters (Ga-6, 0.45 $\mu \mathrm{m}$ pore size) were obtained from Gelman Instrument Company (Ann Arbor, Mich.). Nylon bolting cloth was purchased from Tobler, Ernst and Traber (Elmsford, N.Y.).

Injection procedure and isolation of neuronal perikarya and glial cells. Labelling of brain proteins in vivo was accomplished by a single intrathecal injection, while the rats were under light ether anaesthesia, of an aqueous solution $(0.05 \mathrm{ml})$ of $\mathrm{L}$-[UU- $\left.{ }^{14} \mathrm{C}\right]$ phenylalanine in a dose of $6.25 \mu \mathrm{Ci}$ per brain. At specified intervals the animals were subsequently killed by decapitation. Neuronal perikarya and glial cells were isolated from the cerebral cortex according to the method of SELLINGER et al. (1971). Ten animals were killed and the brains were rapidly excised and placed on an inverted Petri dish covered with filter paper and resting on crushed ice. The cerebral cortices, dissected as free as possible of underlying white matter, were chopped with a razor blade into the consistency of a mince, which was transferred into $10-15 \mathrm{ml}$ of an ice-cold solution of $7.5 \%(\mathrm{w} / \mathrm{v}) \mathrm{PVP}, 1 \%(\mathrm{w} / \mathrm{v}) \mathrm{BSA}$ and $10 \mathrm{mM}_{-} \mathrm{CaCl}_{2}$. The tissue mince was then eased into a truncated disposable syringe and the plunger was used to push the mince suspension through one thickness of nylon bolting cloth of $333 \mu \mathrm{m}$ pore size stretched over the open end of the syringe. This sieving was repeated twice and the last filtrate was allowed to stand on ice for $10 \mathrm{~min}$. Sieving was continued by three successive passes through an inner layer of $333 \mu \mathrm{m}$ and an outer layer of $110 \mu \mathrm{m}$ pore size mylon mesh and, after $10 \mathrm{~min}$ on ice, by similar passage through an inner layer of $333 \mu \mathrm{m}$ and an outer layer of $73 \mu \mathrm{m}$ pore size nylon mesh. After 20 min on ice, the last ' $73-\mu \mathrm{m}$ filtrate' (about $65 \mathrm{ml}$ ) was divided into three portions, each of which was layered over a two-step gradient of $6 \mathrm{ml}$ of $1.0 \mathrm{M}$-sucrose and $5 \mathrm{ml}$ of $1.75 \mathrm{M}$-sucrose containing $1 \%(w / v)$ BSA. The tubes were centrifuged in the SW-25.1 Spinco rotor at $41,000 \mathrm{~g}$ for $30 \mathrm{~min}$. They then contained a top band of myelin, a band of nerve fibres, capillaries and impure glial cells at the $1.0 \mathrm{M}-1.75 \mathrm{M}$-sucrose interface and a pellet of pure neuronal perikarya.

The band of impure glial cells was collected to include most of the 1.75 M-sucrose under it and was mixed with 1.5 vol. of a solution containing $5 \%(w / v)$ Ficoll, $7.5 \%(w / v)$ PVP and $1 \%(w / v)$ BSA, whereupon it was centrifuged at $500 \mathrm{~g}$ for $10 \mathrm{~min}$. A suspension of the resulting pellet was passed thrice through the $73 \mu \mathrm{m}$ nylon mesh and was brought to a vol. of $45-60 \mathrm{ml}$. It was divided into three samples, each of which was layered over a gradient of $3 \mathrm{ml}$ of $30 \%(\mathrm{w} / \mathrm{v})$ Ficoll, $6 \mathrm{ml}$ of $1.2 \mathrm{M}$-sucrose and $5 \mathrm{ml}$ of $1.65 \mathrm{M}$-sucrose, all solutions also containing $1 \%(\mathrm{w} / \mathrm{v}) \mathrm{BSA}$. The tubes were centrifuged in the SW-25.1 Spinco rotor at $41,000 \mathrm{~g}$ for $30 \mathrm{~min}$. The pellets and the bands collecting at the sucroseFicoll interface were discarded and the 1.2-1.65 $\mathrm{M}$-sucrose bands were kept and brought to a vol. of 18-22 $\mathrm{ml}$ with $0.32 \mathrm{M}$-sucrose. The tube was centrifuged at $500 \mathrm{~g}$ for $12 \mathrm{~min}$ and the pellet was resuspended in $0.32 \mathrm{M}$-sucrose. The suspension was passed through one thickness of the $73 \mu \mathrm{m}$ nylon mesh and, after dilution with $0.32 \mathrm{M}$-sucrose to about $20 \mathrm{ml}$, was layered over a gradient of $6 \mathrm{ml}$ of $1.3 \mathrm{M}$-sucrose and $5 \mathrm{ml}$ of $1.65 \mathrm{M}$-sucrose which were free of BSA. The tubes were centrifuged in the $\mathrm{SW}-25.1$ Spinco rotor at $2500 \mathrm{~g}$ for $20 \mathrm{~min}$. Purified glial cells were collected from the $1 \cdot 3-1 \cdot 65 \mathrm{M}$ sucrose interface. The last centrifugation step might be repeated in case of significant contamination of the glia by capillaries, as routinely monitored by phase-contrast microscopy.

Subcellular fractionation of the neuronal perikarya. A suspension of the neuronal perikarya was homogenized in $0.25 \mathrm{M}$-sucrose with six up-and-down strokes rotating at about $1300 \mathrm{rev} . / \mathrm{min}$ of a standard Potter-Elvehjem glass-Teflon homogenizer. The $5 \%(w / v)$ homogenate was centrifuged at $800 \mathrm{~g}$ for $10 \mathrm{~min}$ and the pellet was resuspended and centrifuged as just described twice more. The final pellet was designated the nuclear fraction. The pooled post-nuclear supernatant fluids were centrifuged at $18,000 \mathrm{~g}$ for $15 \mathrm{~min}$ and the pellet was resuspended and recentrifuged for $12 \mathrm{~min}$ at $17,300 \mathrm{~g}$, yielding as the pellet, the crude mitochondrial fraction. The pooled post-mitochondrial supernatant fluids were centrifuged in the Spinco 65 rotor at $100,000 \mathrm{~g}$ for $60 \mathrm{~min}$ to give the microsomal (pellet) and the cell sap (soluble) fractions.

Measurement of radioactivity. The radioactivity was measured in a Nuclear Chicago Unilux II spectrometer at a counting efficiency of 75-85 per cent. Quenching corrections were carried out by the channels-ratio method and by the use of an internal standard. The c.p.m. were converted to d.p.m. using a suitable program on the PDP- 8 computer. The composition of the scintillation fluid was $4 \mathrm{~g}$ of 
PPO and $0.1 \mathrm{~g}$ of dimethyl POPOP per 1 . of toluene. The total radioactivity was determined by mixing $1 \mathrm{ml}$ of the sample with $2 \mathrm{ml}$ of Biosolv- 3 and $10 \mathrm{ml}$ of the toluene scintillation fluid. The ${ }^{14} \mathrm{C}$-labelled protein was precipitated by $1 \mathrm{ml}$ of ice-cold $10 \%(\mathrm{w} / \mathrm{v}) \mathrm{TCA}$ and was adsorbed on Millipore filters (pore size: $0.45 \mu \mathrm{m}$ ). The filters were treated successively with 3 and $2 \mathrm{ml}$ of $5 \%(\mathrm{w} / \mathrm{v})$ ice-cold TCA, 3 and $2 \mathrm{ml}$ of $95 \%(\mathrm{v} / \mathrm{v})$ ethanol and $5 \mathrm{ml}$ of ether. Heating in $5 \%(\mathrm{w} / \mathrm{v}) \mathrm{TCA}$ in the presence of [ $\left.{ }^{12} \mathrm{C}\right]$ phenylalanine carrier, as recommended by ZOMZELY, ROBERTS, GRUBER and BROWN (1968), was found to be unnecessary and was therefore omitted. The filters were transferred to counting vials and dried under an infra-red lamp; $10 \mathrm{ml}$ of the toluene scintillation fluid were added for counting. Protein was determined by the method of LowRY, ROSEBROUGH, FARR and RANDALL (1951) and RNA was measured by the procedure of FLECK and BEGG (1965). For RNA, a factor of 41.6 was used to convert the $\mathrm{A}_{260}$ readings (taken in a final vol. of $1.3 \mathrm{ml}$ ) to $\mu \mathrm{g}$ of $\mathrm{RNA} / \mathrm{ml}$.

Morphological examination of the cells and subcellular fractions. The neuronal perikarya and the glial cells were examined by phase-contrast microscopy (Fig. 1, A-C) and, together with the subcellular fractions of the neuronal perikarya, also by electron microscopy (Fig. 2, A to D). The neuronal perikarya were fixed in pellet form for $2.5 \mathrm{~h}$ at $4^{\circ} \mathrm{C}$ in solution GPS composed of $3 \%(\mathrm{v} / \mathrm{v})$ glutaraldehyde buffered at pH 7.4 with $0.1 \mathrm{M}$-phosphate buffer and containing $5 \%(\mathrm{w} / \mathrm{v})$ sucrose. After fixation, the pellet was minced in the phosphate buffer and was stored at $4^{\circ} \mathrm{C}$. The glial cells, collected as a band (see above), were fixed for $1 \mathrm{~h}$ at $4^{\circ} \mathrm{C}$ in solution GPS in which the concentration of glutaraldehyde was $1.5 \%(\mathrm{v} / \mathrm{v})$. The cells were centrifuged at $3020 \mathrm{~g}$ for $10 \mathrm{~min}$ and the pellet was minced in the phosphate buffer and stored at $4^{\circ} \mathrm{C}$. The subcellular fractions were collected in pellet form and were fixed in solution GPS for $6 \mathrm{~h}$ at $4^{\circ} \mathrm{C}$. After fixation, the pellets were transferred to the phosphate buffer and were stored at $4^{\circ} \mathrm{C}$. Post-fixation was the same for all samples and was for $4 \mathrm{~h}$ in $2 \%(\mathrm{w} / \mathrm{v})$ ice-cold osmium tetroxide in $0.1 \mathrm{M}$-phosphate buffer $(\mathrm{pH} 7.4)$ containing $5 \%(\mathrm{w} / \mathrm{v})$ sucrose. After a brief buffer wash, the samples were brought to room temperature, dehydrated in a graded series of alcohols and treated thrice with propylene oxide. They were kept overnight in a $1: 1(\mathrm{v} / \mathrm{v})$ mixture of Epon 812 and propylene oxide and were then treated with pure Epon 812 for $6 \mathrm{~h}$ before being flat-embedded. The ultra-thin sections mounted on bare 400-mesh copper grids were stained with $5 \%$ (w/v) uranyl acetate and counterstained with lead citrate. The sections were examined in a JEOLCO, JEM 6-A electron microscope.

\section{RESULTS}

Comparison of the neuronal perikarya and the glial cells. The yield (in terms of protein) of neuronal perikarya and glial cells depended markedly on the age of the animal (Table 1); hence, a considerably higher proportion of neuronal perikarya was isolated from the younger rats. Taking the cortical suspension as the parent fraction for reference, the yield of neuronal perikarya dropped from 42.4 per cent in the 5-dayold rat to 0.68 per cent in the 43-day-old rat. When expressed this way, the yield of glial cells changed very little with age; no cells morphologically identifiable as mature glial cells were present in the preparation obtained from a 5-day-old rat, an observation in confirmation of the morphological findings of CALEY and MAXWELL (1968b). There was a common but unequal decrease in the yield of both cell types with maturation. Hence, the NP/G ratio (Table 1) decreased in absolute value, confirming that the cell separation procedure led to the isolation of higher proportions of neuronal perikarya than of glial cells in the younger animal.

For studies relating the yield of both cell types to their selective labelling as a function of postnatal age (Table 2), a ratio of cell yield to cell ${ }^{14} \mathrm{C}$-labelled protein $>1$ indicated the selective isolation of a larger proportion of unlabelled cells, whereas, conversely, a ratio $<1$ indicated that some of the isolated cells were preferentially labelled. In the neuronal perikarya this ratio was $>1$ only at 5 days and was $<1$ later in life, whereas for the glial cells it decreased from values $>1$ at 10 days to a low value at 43 days of 0.42 . The incorporation of $\mathrm{L}-\left[{ }^{14} \mathrm{C}\right]$ phenylalanine into neuronal and glial proteins was studied in 5-, 10-, 18- and 43-day-old rats after a $10 \mathrm{~min}$ pulse in vivo of $\mathrm{L}-\left[{ }^{14} \mathrm{C}\right]$ phenylalanine (Table 3 ). As indicated by the specific radioactivities of the isolated ${ }^{14} \mathrm{C}$-labelled proteins, the ability of neurons to synthesize protein decreased 

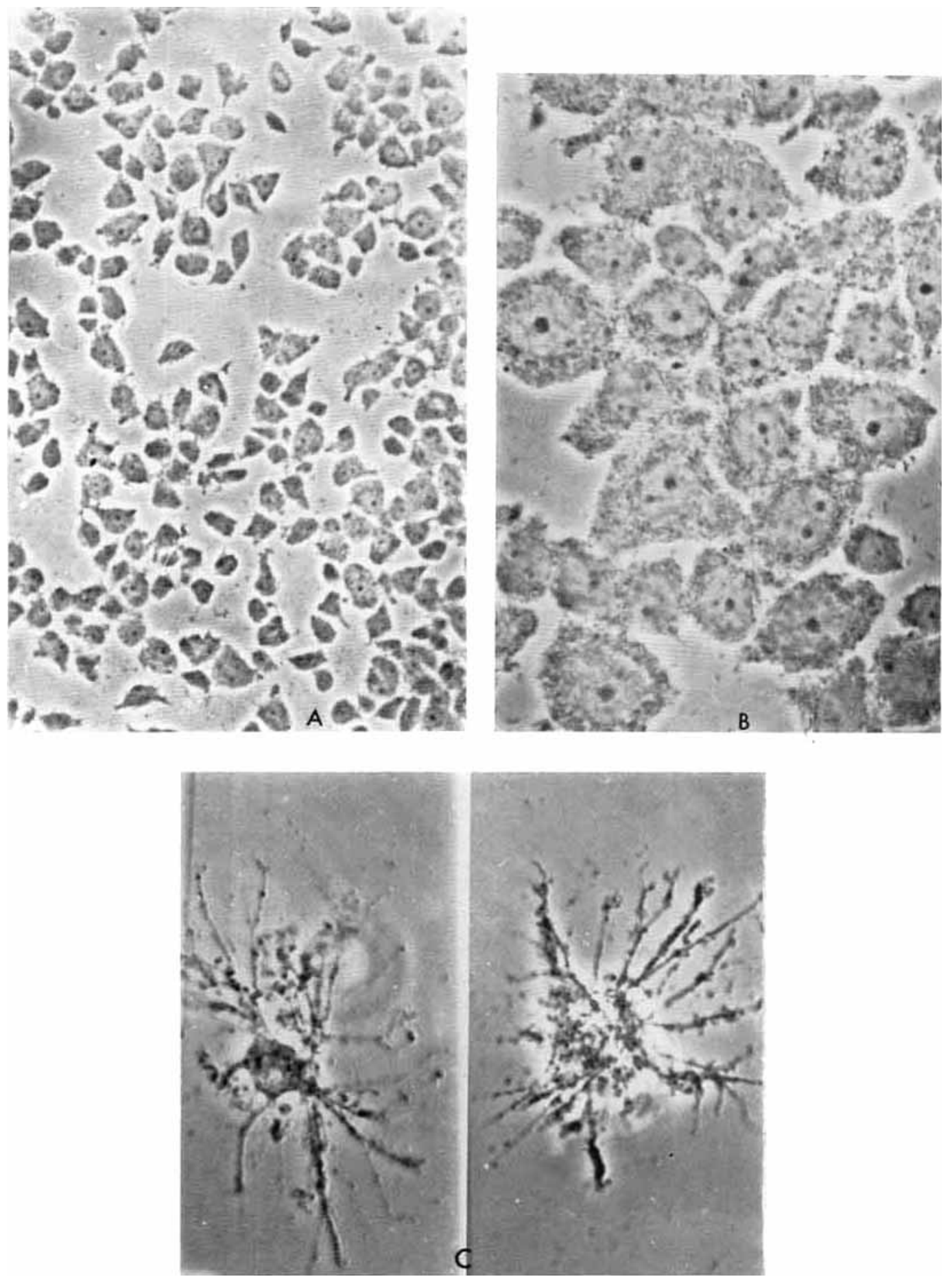

FIG. 1.-Phase contrast photomicrographs. (A) Neuronal perikarya ( $\times 200)$; 18-day-old cerebral cortex of the rat; (B) Neuronal perikarya $(\times 800)$; 18-day-old cerebral cortex; (C) Glial cells $(\times 1000)$ the two cells were from the cerebral cortex of a 38-day-old rat. Note that not all structural features could be photographed in focus. 


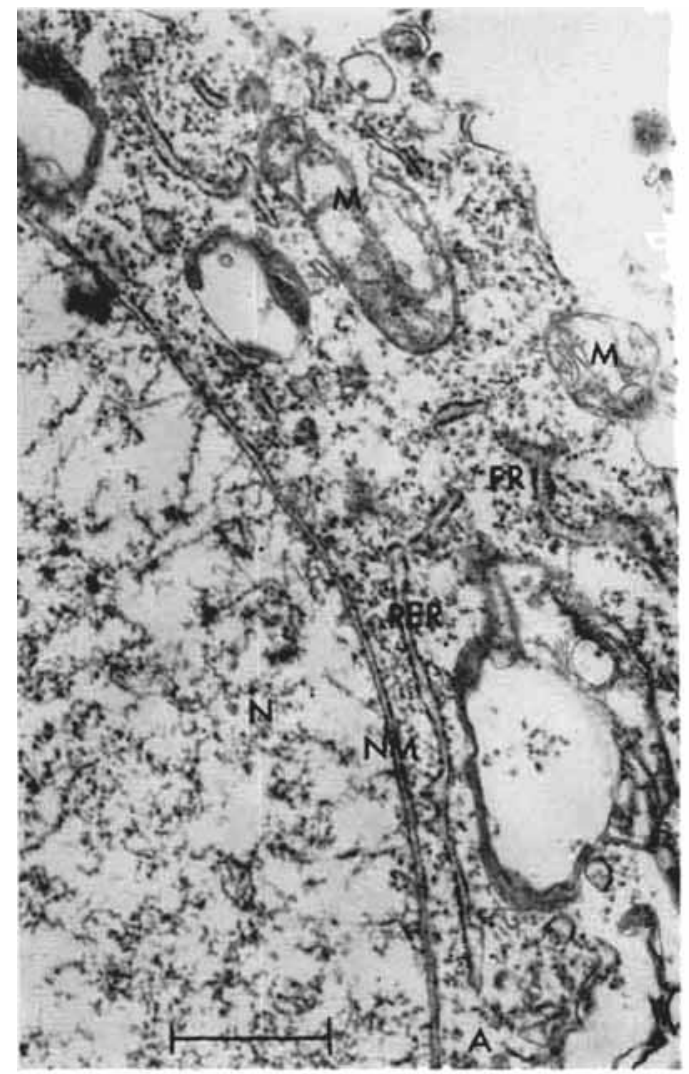

FIG. 2A

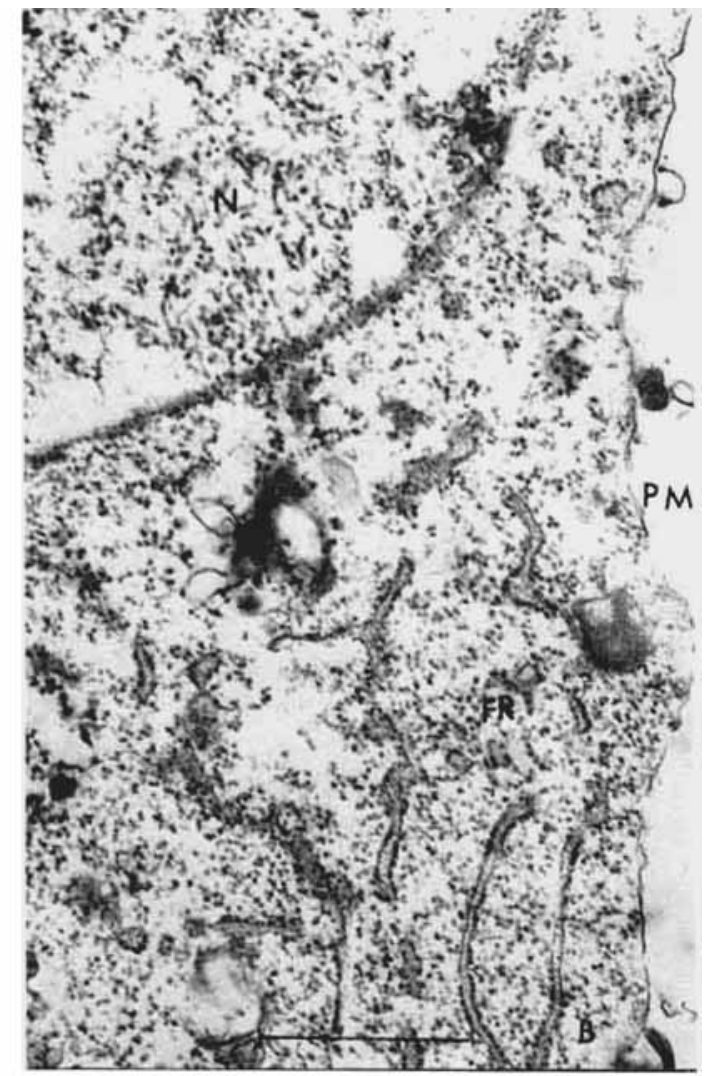

FIG. 2B 

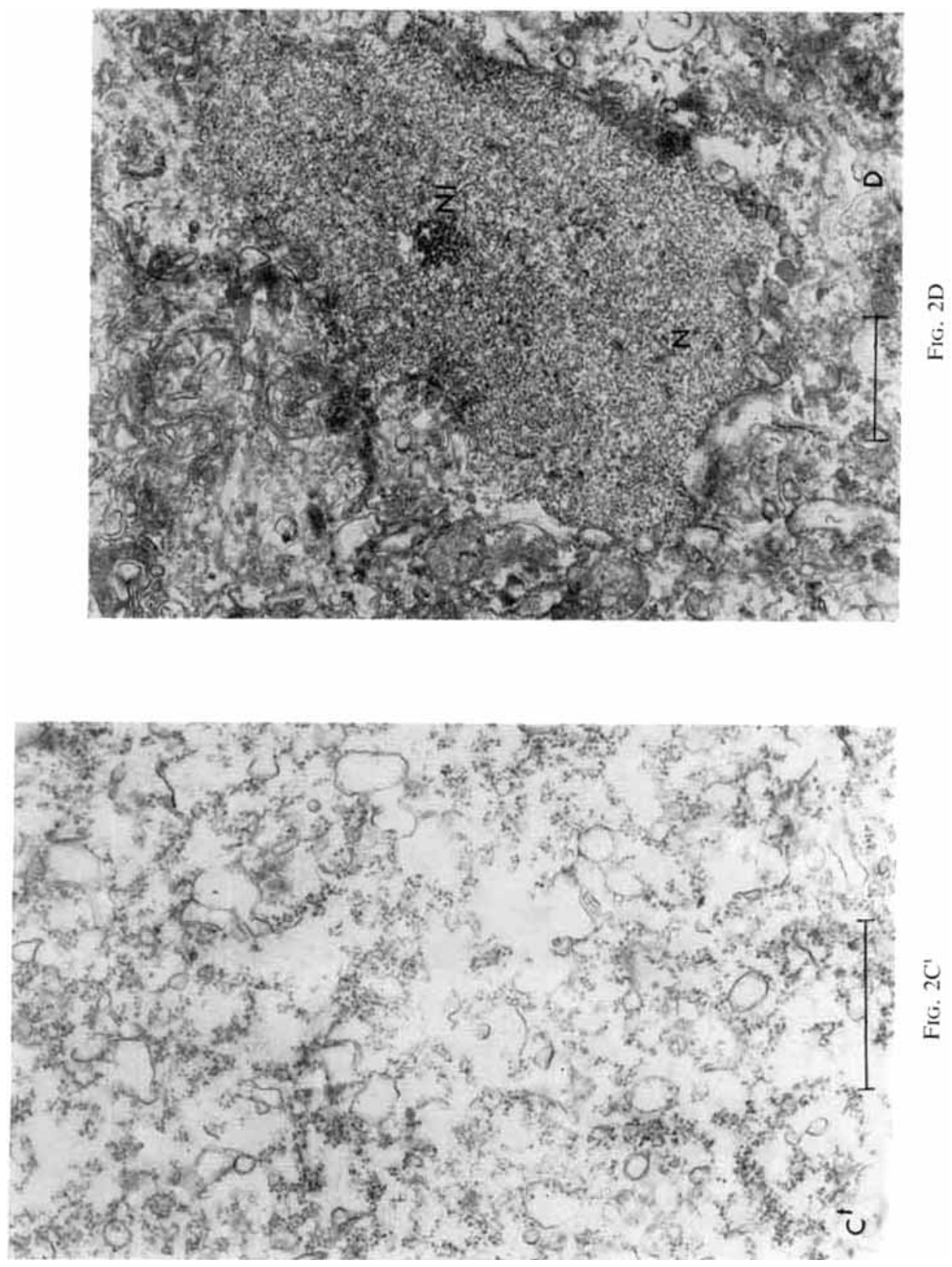


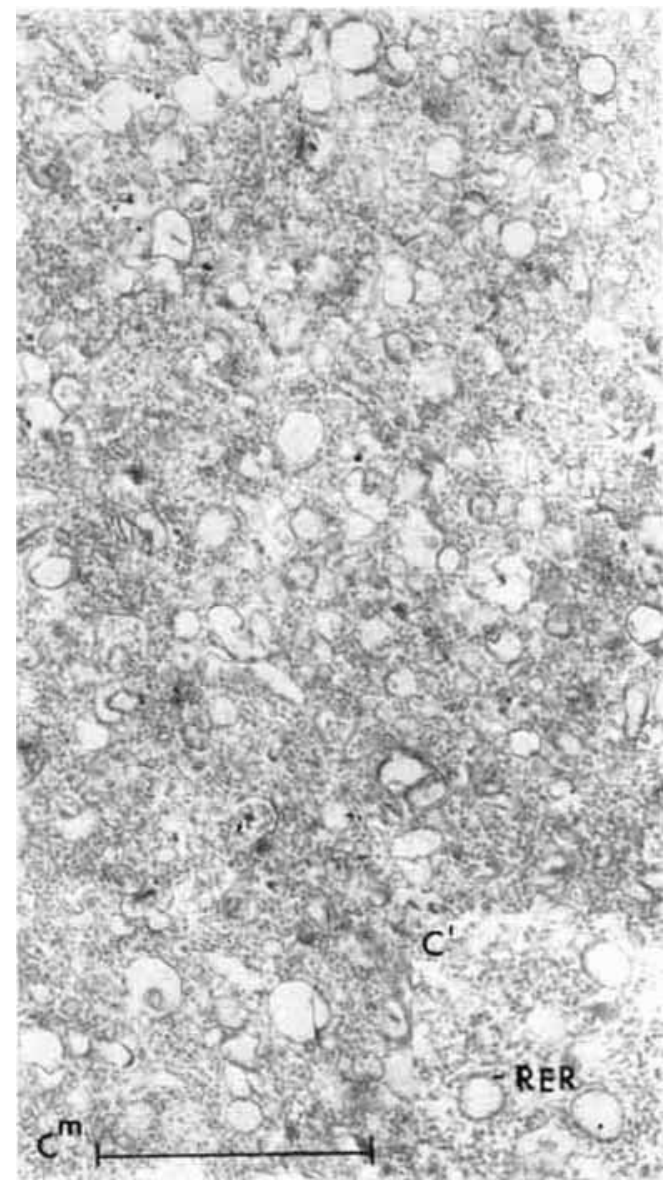

FIG $2 \mathrm{C}^{\mathrm{m}}$ and $\mathrm{C}^{1}$

FIG. 2.-Electron micrographs. (A) Neuronal perikaryon from the cerebral cortex of an 18-day-old rat, detail $(\times 10,000)$. (B) Same as A $(\cdot 10,000)$; (C) Field showing the appearance of the microsomal fraction; 18-day-old cerebral cortex was used $(\times 10,200)$, with a section through the top $(\mathrm{C})^{\mathrm{t}}$ and middle $\left(\mathrm{C}^{\mathrm{m}}\right)$ portions of the microsomal pellet (see Methods); the inset $\left(C^{1}\right)$ shows a detail of a microsomal preparation demonstrating the presence of 'bound' ribosomes (studding the membrane of the endoplasmic reticulum); (D) Glial cell from the cerebral cortex of an 18-day-old rat $(\times 10,000)$. Scale marker represents one $\mu \mathrm{m}$. Abbreviations used: N, nucleus; Nl, nucleolus; M, mitochondrion: FR, free ribosomes; RER, rough endoplasmic reticulum; PM, plasma membrane; NM, nuclear membrane. 


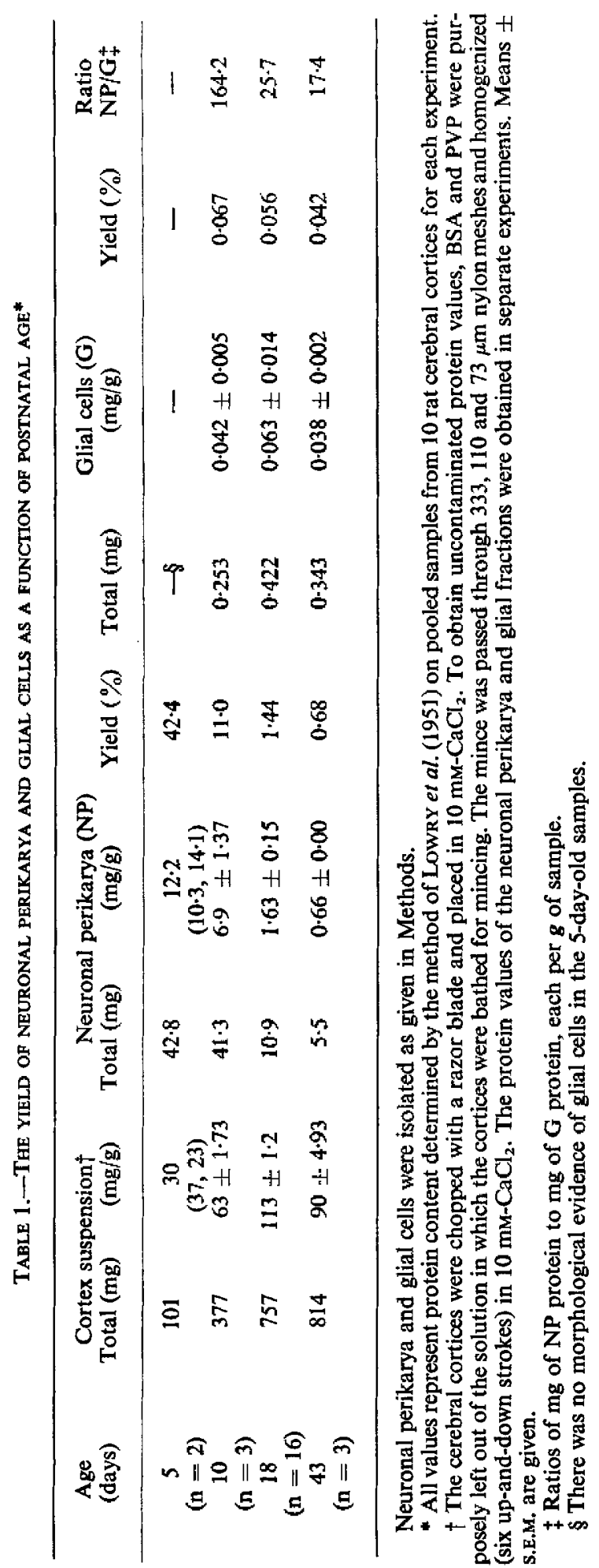


TABle 2.-Cell YLeld vs. CELL ${ }^{14}$ C-LABELled PRotein:* THE INFLUENCE OF AGE

\begin{tabular}{|c|c|c|}
\hline & $\%$ Neuronal perikarya & $\%$ Glial cells \\
\hline (days) & $\%{ }^{14} \mathrm{C}$-labelled protein $\dagger$ & $\%{ }^{14} \mathrm{C}$-labelled protein ${ }_{+}^{+}$ \\
\hline $5(n=2)$ & $\begin{array}{l}1.89 \\
(1.87,1.91)\end{array}$ & $(?) \S$ \\
\hline $\begin{array}{l}10(n=3) \\
18(n=4) \\
43(n=3)\end{array}$ & $\begin{array}{l}0.90 \pm 0.025 \\
0.64 \pm 0.021 \\
0.84 \pm 0.028\end{array}$ & $\begin{array}{l}1.60 \pm 0.69 \\
1.00 \pm 0.031 \\
0.42 \pm 0.020\end{array}$ \\
\hline
\end{tabular}

The in vivo pulse of $\mathrm{L}-\left[{ }^{14} \mathrm{C}\right]$ phenylalanine was $10 \mathrm{~min}$. Neuronal perikarya and glial cells were isolated as described in Methods.

Except where individual values are listed ( 5 days), mean values \pm s.E.M. are given. The percentage of glial cells was obtained by dividing the protein of the glial cells by the protein of the cortex suspension (Table 1) $\times 100$.

- ${ }^{14}$ C-labelled protein refers to TCA-precipitable, Millipore-treated radioactivity, as described under Methods.

$\dagger$ Percentage ${ }^{14} \mathrm{C}$-labelled protein $=\frac{\text { d.p.m. in NP }}{\text { d.p.m. in cortex suspension }} \times 100$

$¥$ Percentage ${ }^{14} \mathrm{C}$-labelled protein $=\frac{\text { d.p.m. in G }}{\text { d.p.m. in cortex suspension }} \times 100$

$\S$ There was no morphological evidence of glial cells in the 5-day-old samples.

progressively, whereas that of the glial cells increased during the period 10 to 18 days and then decreased during the period 18 to 43 days of age. The specific radioactivity of both cell types was lowest in the 43-day-old rat. Also, the specific radioactivity of the neurons was higher than that of the glial cells at all ages except at 43 days, when that of the glial cells was higher. Therefore, at 43 days the $N P / G$ ratio for these data was $<1$. The time course of neuronal and glial protein synthesis was assessed in vivo by determining the incorporation of $\mathrm{L}-\left[{ }^{14} \mathrm{C}\right]$ phenylalanine into ${ }^{14} \mathrm{C}$-labelled protein at 5,10 ,

TABle 3.-The SPECIFIC RADIOACTIVITY OF NEURONAL AND GLIAL ${ }^{14}$ C-LABELled PRoteIn:* THE EFFECT OF AGE

\begin{tabular}{|c|c|c|c|c|}
\hline Cell type & $\begin{array}{c}5 \text { days } \\
\text { (d.p.m. } / \mathrm{mg}, \mathrm{n}=2 \text { ) }\end{array}$ & $\begin{array}{c}10 \text { days } \\
\text { (d.p.m. } / \mathrm{mg}, \mathrm{n}=3 \text { ) }\end{array}$ & $\begin{array}{c}18 \text { days } \\
\text { (d.p.m. } / \mathrm{mg}, \mathrm{n}=4)\end{array}$ & $\begin{array}{l}43 \text { days } \\
\text { (d.p.m. } / \mathrm{mg}, \mathrm{n}=3 \text { ) }\end{array}$ \\
\hline $\begin{array}{l}\text { Neuro nal } \\
\text { peri karya (NP) }\end{array}$ & $\begin{array}{c}3204 \\
(3892 ; 2515)\end{array}$ & $3127 \pm 320$ & $2869 \pm 326$ & $463 \pm 99$ \\
\hline $\begin{array}{l}\text { Glia (G) } \\
\mathrm{NP} / \mathrm{G}\end{array}$ & $?+\uparrow$ & $\begin{array}{c}1793 \pm 415 \\
1 \cdot 74\end{array}$ & $\begin{array}{c}2205 \pm 368 \\
1 \cdot 30\end{array}$ & $\begin{array}{l}853 \pm 85 \\
0.54\end{array}$ \\
\hline
\end{tabular}

Except where individual values are listed ( 5 days), mean values \pm S.E.M. are given.

Rats were injected intrathecally with $50 \mu$ of aqueous $L-\left[U-{ }^{14} \mathrm{C}\right]$ phenylanaline in a dose of $6 \cdot 25 \mu \mathrm{Ci}$ per brain and killed after an in vivo pulse of $10 \mathrm{~min}$. Neuronal perikarya and glial cells were isolated as described in Methods.

${ }^{*}{ }^{14}$ C-labelled protein refers to TCA-precipitable, Millipore-treated radioactivity, as described under Methods.

† There was no morphological evidence of glial cells in the 5-day-old samples. 


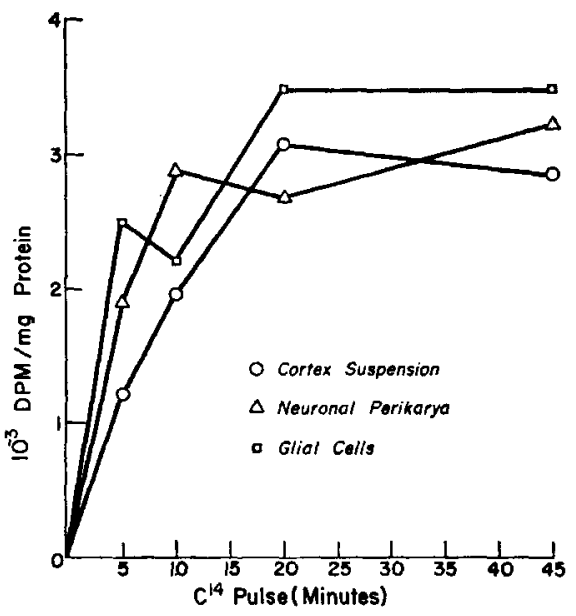

FIG. 3.-Incorporation of $\mathrm{L}-\left[{ }^{14} \mathrm{C}\right]$ phenylalanine into proteins of the cerebral cortex, neuronal perikarya and glial cells of 18-day-old rats as a function of pulse time. Rats were injected intrathecally with $50 \mu 1$ of an aqueous solution of L-[U-14C]phenylalanine in a dose of $6.25 \mu \mathrm{Ci}$ per brain and killed at the desired times. The cerebral cortex, neuronal perikarya and glial cells were isolated as described in Methods and the specific radioactivities (d.p.m./mg of protein) were determined. Values are the averages of four experiments for the cerebral cortex and neuronal perikarya and three experiments for the glial cells. The S.E.M. for the 5, 10, 20 and 45-min pulses were respectively: for cortex suspension: $\pm 97, \pm 334, \pm 451$ and \pm 448 ; for neuronal perikarya: $\pm 39, \pm 326, \pm 764$ and \pm 316 ; for glial cells: $\pm 756, \pm 520, \pm 429$ and \pm 1116 .

20 and 45 min after administration (Fig. 3). Labelling of the protein was rapid but unequal, reaching near maximum values in the neurons within $10 \mathrm{~min}$ and in the glial cells within $20 \mathrm{~min}$ from the time of administration of $\mathrm{L}-\left[{ }^{14} \mathrm{C}\right]$ phenylalanine. The relative rates of incorporation of $\mathrm{L}-\left[{ }^{14} \mathrm{C}\right]$ phenylalanine were initially faster for the glial cells than for the neurons, as indicated by higher values for specific radioactivity in glial cells at $5 \mathrm{~min}$. At $10 \mathrm{~min}$, however, the specific radioactivity of the neuronal ${ }^{14} \mathrm{C}$-labelled protein exceeded that of the glial ${ }^{14} \mathrm{C}$-labelled protein.

Protein and RNA content in the subcellular fractions of the neuronal perikarya. The protein content of the subcellular fractions of the neuronal perikarya varied with age (Table 4). Thus, the amount of protein in the nuclear and microsomal fractions decreased and that in the mitochondrial and cell sap fractions increased with increasing postnatal age (MURTHY and RAPPOPORT, 1965). The subcellular distribution of RNA in the neuronal perikarya was determined in the 18-day-old rat (Table 5). A high proportion of RNA (54.4 per cent) characterized the microsomal fraction (Fig. 2C), whereas the cell sap fraction contained only $10 \cdot 3$ per cent of the total RNA. Consequently, the ratios of percentage RNA/percentage protein ranged from 0.19 for the cell sap to $4 \cdot 3$ for the microsomal fraction, with the remaining fractions averaging about 1.0 .

Effect of pulse duration and of age on the incorporation of $\left[{ }^{14} C\right]$ phenylalanine into proteins in the subcellular fractions of neuronal perikarya. Subfractionation of a homogenate of the neuronal perikarya derived from 18-day-old rats injected with $\mathrm{L}-\left[{ }^{14} \mathrm{C}\right]-$ phenylalanine revealed that the distribution of the ${ }^{14} \mathrm{C}$-labelled protein was affected by the pulse time in vivo (Table 6). The mitochondrial fraction comprised about 


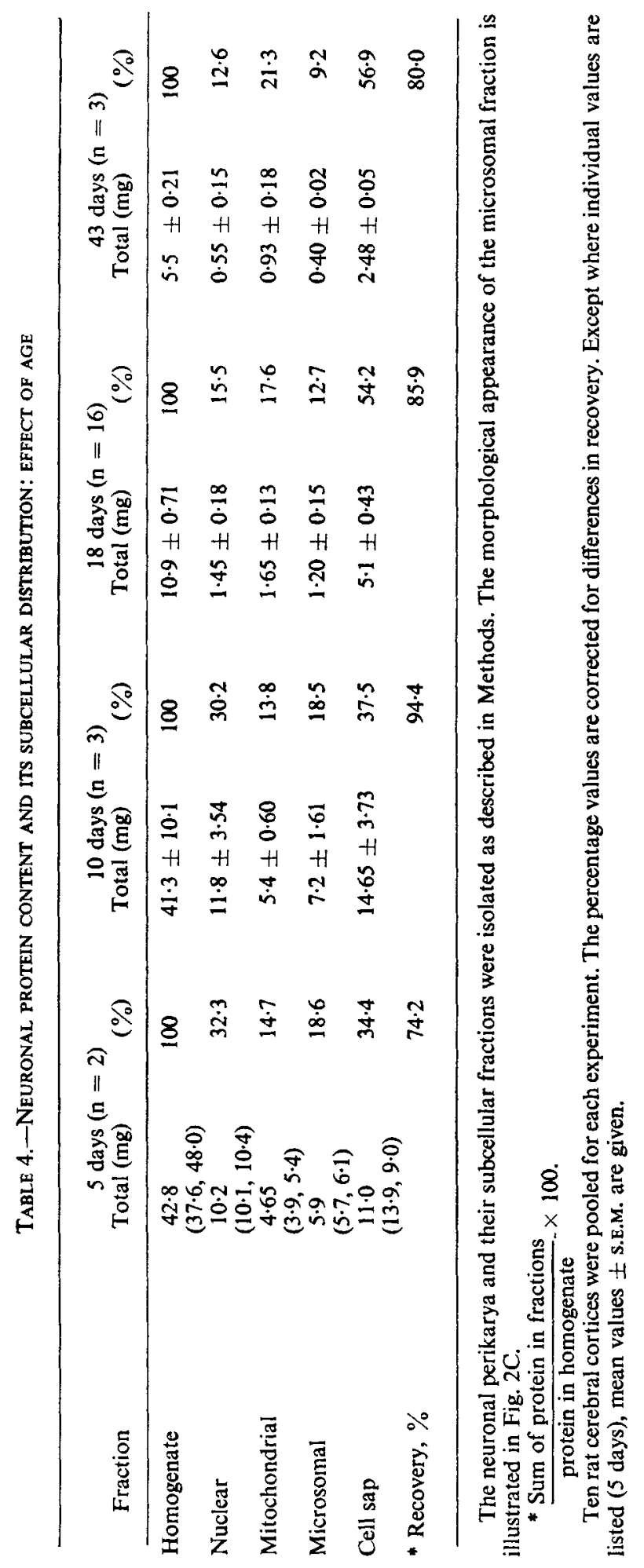


TABLE 5.-THE SUBCELLULAR DISTRIBUTTON OF RNA IN NEURONAL PERIKARYA

\begin{tabular}{llcc}
\hline \multicolumn{1}{c}{ Fraction } & $\begin{array}{c}\text { RNA } \\
(\mathrm{mg})\end{array}$ & $\begin{array}{c}\text { RNA } \\
(\%)\end{array}$ & $\%$ RNA/\% protein \\
\hline Homogenate & 1.516 & 100 & 1.0 \\
Nuclear & $0.199 \pm 0.007$ & 16.0 & 1.03 \\
Mitochondrial & $0.241 \pm 0.004$ & $19 \cdot 3$ & 1.10 \\
Microsomal & $0.678 \pm 0.024$ & 54.4 & 4.28 \\
Cell sap & $0.129 \pm 0.003$ & 10.3 & 0.19 \\
*ecovery, \% & & 82.3 & \\
\hline
\end{tabular}

The cerebral cortices of ten 18-day-old rats were used for each experiment. Initial weight of the pooled cortices: $6.7 \mathrm{~g}$.

Values are normalized to 100 per cent recovery and are the means \pm S.E.M. of six experiments. See Methods for details of fractionation and analytical procedures.

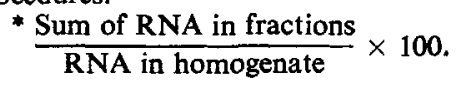

50 per cent of the ${ }^{14} \mathrm{C}$-labelled proteins after a 20 -min pulse, whereas at that time the microsomal fraction comprised less than 30 per cent of the total. At all pulse times the cell sap comprised less than 10 per cent of the ${ }^{14} \mathrm{C}$-labelled proteins. Sellinger, AzCURRA, IDOYAGA-VARGAS and SANriago (unpublished) have shown peaks of specific activity of succinate and glycerol-phosphate dehydrogenases (EC 1.3.99.1 and 1.1.1.8) in the mitochondrial fraction, of $N$-acetyl- $\beta$-D-glucosaminidase in the lysosomal fraction and of lactate dehydrogenase (EC 1.1.1.27) in the soluble cell sap fraction, thus confirming the relative intactness of the isolated cell bodies. On the other hand, more recently (JOHNSON and SELLINGER, in preparation) the soluble perikaryal proteins could be appreciably labelled, provided the exposure of the cells to $\mathrm{L}-\left[{ }^{14} \mathrm{C}\right]$ phenylalanine

TABLE 6.-THE SUBCELlULAR DisTRIBUTION OF ${ }^{14} \mathrm{C}$-LABELlED PROTEIN ${ }^{*}$ IN NEURONAL PERIKARYA: THE EFFECT OF PULSE DURATION

\begin{tabular}{|c|c|c|c|c|}
\hline Fraction & $\begin{array}{c}5 \min \\
(\%)\end{array}$ & $\begin{array}{c}10 \min \\
(\%)\end{array}$ & $\begin{array}{c}20 \mathrm{~min} \\
(\%)\end{array}$ & $\begin{array}{c}45 \min \\
(\%)\end{array}$ \\
\hline $\begin{array}{l}\text { Nuclear } \\
\text { Mitochondrial } \\
\text { Microsomal } \\
\text { Cell sap } \\
\dagger \text { Recovery, \% }\end{array}$ & $\begin{array}{c}19.0 \pm 1.54 \\
34.5 \pm 4.36 \\
37.9 \pm 4.09 \\
8.6 \pm 1.37 \\
92.8\end{array}$ & $\begin{array}{c}19.4 \pm 1.98 \\
35.9 \pm 5.50 \\
36.5 \pm 3.77 \\
8.2 \pm 2.93 \\
106.5\end{array}$ & $\begin{array}{c}19.3 \pm 3.91 \\
50.6 \pm 6 \cdot 16 \\
25 \cdot 2 \pm 1.02 \\
4.9 \pm 1.39 \\
89.6\end{array}$ & $\begin{array}{c}23.4 \pm 2.98 \\
38.4 \pm 3.78 \\
29.2 \pm 3.90 \\
9.0 \pm 3.17 \\
92.4\end{array}$ \\
\hline
\end{tabular}

Rats of 18 days were injected as described in Table 3 and killed at the desired times. The neuronal perikarya and their subcellular fractions were isolated as described in Methods.

Values are expressed in percentages and are corrected for differences in recovery. Each value is the mean of four experiments \pm S.E.M.

* ${ }^{14} \mathrm{C}$-labelled protein refers to TCA-precipitable, Millipore-treated radioactivity, as described in Methods.

$$
\uparrow \frac{\text { Sum of d.p.m. in fractions }}{\text { d.p.m. in homogenate }} \times 100 \text {. }
$$




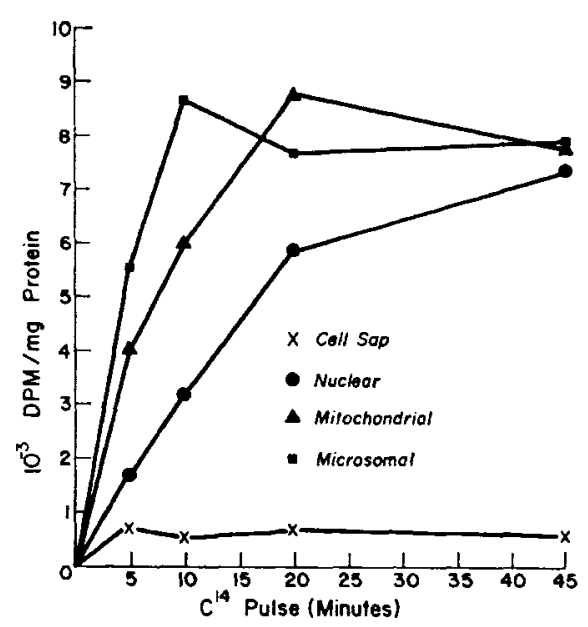

FIG. 4.-Incorporation of $\mathrm{L}-\left[{ }^{14} \mathrm{C}\right]$ phenylalanine into proteins of the subcellular fractions of neuronal perikarya from 18-day-old rat brains as a function of pulse time. Rats were injected intrathecally with $50 \mu \mathrm{l}$ of an aqueous solution of $\mathrm{L}-\left[\mathrm{U}-{ }^{14} \mathrm{C}\right]$ phenylalanine in a dose of $6.25 \mu \mathrm{Ci}$ per brain and killed at the desired times. The subcellular fractions were isolated as described in Methods and the specific radioactivities (d.p.m./mg of protein) were determined. Values are the averages of four experiments. The S.E.M. for the 5,10 , 20 and 45-min pulses were respectively: for cell sap: $\pm 173, \pm 165, \pm 361$ and \pm 217 ; for nuclei : $\pm 185, \pm 418, \pm 1158$ and \pm 1652 ; for mitochondria: $792,1673,2314,1437$; for microsomes; $\pm 990, \pm 1964, \pm 2208$ and \pm 1020 .

in vivo was of longer duration ( 1 day to 2 weeks). The microsomal fraction exhibited the highest specific radioactivity at $10 \mathrm{~min}$ (Fig. 4) but by $20 \mathrm{~min}$, the mitochondrial fraction became the most highly labelled fraction. The specific radioactivity of the nuclear fraction increased steadily over the 45 -min experimental period, whereas that of the cell sap changed very little and remained the lowest of all fractions.

The distribution of the ${ }^{14} \mathrm{C}$-labelled proteins among the subcellular fractions of the neuronal perikarya derived, after a 10-min pulse in vivo, from 5-, 10-, 18- and 43-dayold rats revealed age-dependent differences (Table 7). Thus, while the nuclear fraction comprised about 20 per cent of the ${ }^{14} \mathrm{C}$-labelled protein at all ages, the share of the mitochondrial fraction rose progressively from about 13 per cent in the 5-day-old rat to 46 per cent in the 43-day-old rat and conversely, the amount of ${ }^{14} \mathrm{C}$-labelled protein in the microsomal and cell sap fractions decreased progressively over the same age period. A comparison of the specific radioactivities also revealed age-dependent differences (Fig. 5). The labelling of the nuclear fraction was fairly constant up to 18 days but declined thereafter, whereas that of the mitochondrial fraction increased from 5 to 18 days and also declined thereafter. The microsomal fraction was labelled most rapidly at all ages, but microsomes from the 43-day-old rat exhibited only 15 per cent of the activity found in the microsomes from 5-day-old rats. Under the conditions of our experiments, the soluble neuronal proteins were only moderately labelled in the 5-day-old rat and, as already mentioned, not at all in the 43-day-old animal. In absolute terms, the cell sap fraction was the least labelled of all the subcellular fractions studied at any age by the pulse-labelling technique.

TCA-soluble radivactivity. To determine the effect of the duration of the radioactive pulse and of age on the efficiency of utilization of $\mathrm{L}-\left[{ }^{14} \mathrm{C}\right]$ phenylalanine, we attempted 


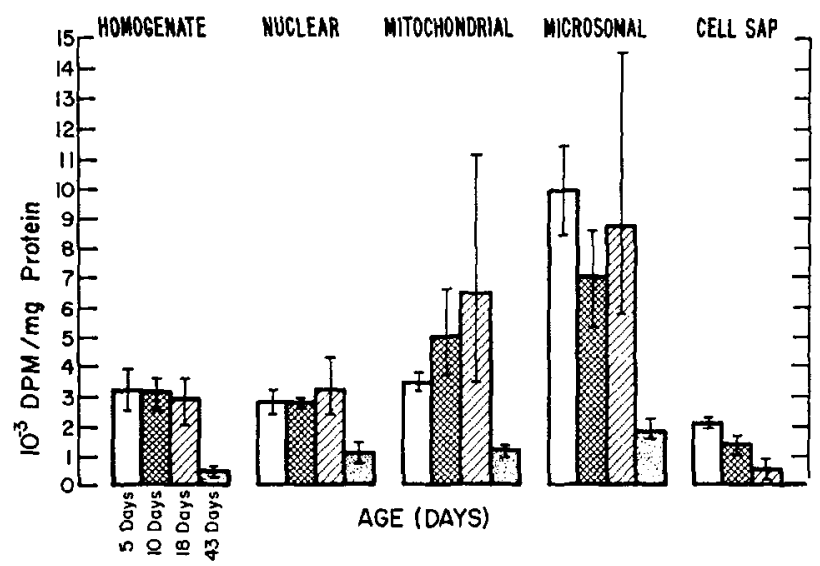

Frg. 5.-The incorporation in vivo of $\left[{ }^{14} \mathrm{C}\right]$ phenylalanine into proteins of the neuronal perikarya and their subcellular fractions from rats of various ages. Rats were injected intrathecally with $50 \mu$ of an aqueous solution of $L-\left[U-{ }^{14} C\right]$ phenylalanine in a dose of $6.25 \mu \mathrm{Ci}$ per brain and killed after an in vivo pulse of $10 \mathrm{~min}$. The neuronal perikarya and the subcellular fractions were isolated as described in Methods and the specific radioactivities (d.p.m./mg of protein) were determined. Each value is the average of four experiments and the vertical lines on the bars represent the range of values. Note the value of zero d.p.m./mg for the cell sap of 43-day-old rat.

TABle 7.-The SUbCEllular distribution of ${ }^{14}$ C-LABElled PROTEIN* IN NEURONAL PERIKARYA: EFFECT OF AGE

\begin{tabular}{|c|c|c|c|c|}
\hline Fraction & $\begin{array}{c}5 \text { days }(n=2) \\
(\%)\end{array}$ & $\begin{array}{c}10 \text { days }(n=3) \\
(\%)\end{array}$ & $\begin{array}{c}18 \text { days }(n=4) \\
(\%)\end{array}$ & $\begin{array}{c}43 \text { days }(n=3) \\
(\%)\end{array}$ \\
\hline Nuclear & $\begin{array}{c}23 \cdot 0 \\
(23 \cdot 5,22 \cdot 3)\end{array}$ & $24.0 \pm 1.94$ & $19.4 \pm 1.98$ & $23 \cdot 2 \pm 4 \cdot 47$ \\
\hline Mitochondrial & $\begin{array}{c}12 \cdot 9 \\
(10 \cdot 6,15 \cdot 1)\end{array}$ & $21 \cdot 5 \pm 3.49$ & $35.9 \pm 5 \cdot 50$ & $45 \cdot 8 \pm 3 \cdot 17$ \\
\hline Microsomal & $\begin{array}{c}46 \cdot 0 \\
(46 \cdot 9,45 \cdot 0)\end{array}$ & $38 \cdot 7 \pm 2 \cdot 17$ & $36.5 \pm 3 \cdot 77$ & $31 \cdot 0 \pm 4 \cdot 57$ \\
\hline Cell sap & $\begin{array}{c}18 \cdot 1 \\
(18 \cdot 9,17 \cdot 6)\end{array}$ & $15.8 \pm 1.76$ & $8 \cdot 2 \pm 2 \cdot 93$ & $0.0 \pm 0.00$ \\
\hline † Recovery, \% & $94 \cdot 5$ & $103 \cdot 0$ & $106 \cdot 5$ & $99 \cdot 6$ \\
\hline
\end{tabular}

Conditions of injection and killing are given in Table 3. The neuronal perikarya and their subcellular fractions were isolated as described in Methods.

Except where individual percentages are listed ( 5 days) mean values \pm S.E.M. are given. All values were corrected for differences in recovery.

${ }^{*}{ }^{14} \mathrm{C}$-labelled protein refers to TCA-precipitable, Millipore-treated radioactivity, as described in Methods.

$\dagger \frac{\text { Sum of d.p.m. in fractions }}{\text { d.p.m. in homogenate }} \times 100$.

to estimate, after a 10 min pulse, the TCA-soluble radioactivity in three fractions of the 18-day-old brain cortex (Table 8) and at four ages (Table 9). TCA-soluble radioactivity decreased rapidly in the cortical suspension during the period between 5 and 45 min (Table 8). In the neuronal perikarya, the loss of TCA-soluble counts was initially also 
very rapid, as indicated by the finding at $5 \mathrm{~min}$ of more than 50 per cent of the perikaryal radioactivity no longer in this form; yet, at later times the utilization of the administered radioactivity for synthesis of proteins abated appreciably, so that at 45 min almost two-thirds of the perikaryal counts were still TCA-soluble. The efficiency of utilization of $\left[{ }^{14} \mathrm{C}\right]$ phenylalanine decreased markedly with age (Table 9), to the point where at 43 days 100 per cent of the radioactivity in the neuronal cell sap was still TCA-soluble at $10 \mathrm{~min}$ after administration of $\mathrm{L}-\left[{ }^{14} \mathrm{C}\right]$ phenylalanine.

TABLE 8.-ThE EFFECT OF PULSE TIME ON THE TCA-SOLUBLE RADIOACTIVITY

\begin{tabular}{|c|c|c|c|c|}
\hline Fraction & $5 \mathrm{~min}$ & $10 \mathrm{~min}$ & $20 \mathrm{~min}$ & $45 \mathrm{~min}$ \\
\hline $\begin{array}{l}\text { Cortex suspension } \\
{ }^{*}(\mu \mathrm{mol} / \text { cortex })\end{array}$ & $11.5 \pm 0.97$ & $7 \cdot 2 \pm 1 \cdot 24$ & $4.3 \pm 1.03$ & $2 \cdot 6 \pm 0.51$ \\
\hline $\begin{array}{l}\text { Cortex suspension }(\%) \\
\text { Neuronal perikarya }(\%) \\
\text { Neuronal cell sap }(\%)\end{array}$ & $\begin{array}{l}94.1 \pm 0.46 \\
48.5 \pm 4.69 \\
70.8 \pm 7.65\end{array}$ & $\begin{array}{l}79 \cdot 1 \pm 4 \cdot 00 \\
58 \cdot 5 \pm 4 \cdot 10 \\
79.9 \pm 7 \cdot 59\end{array}$ & $\begin{array}{l}60.7 \pm 5.09 \\
66.0 \pm 6.59 \\
84.4 \pm 6.43\end{array}$ & $\begin{array}{l}49 \cdot 7 \pm 3 \cdot 66 \\
63 \cdot 5 \pm 2 \cdot 25 \\
83 \cdot 1 \pm 5.01\end{array}$ \\
\hline
\end{tabular}

The fractions were prepared as described in Methods. The TCA-soluble activity was the difference between the total radioactivity and the TCA-precipitable, Millipore-treated radioactivity.

The dose of $\left[{ }^{14} \mathrm{C}\right]$ phenylalanine was $17 \mathrm{nmol} / \mathrm{brain}$. In the top line the values are expressed as $\mu$ mol/cortex \pm S.E.M. after multiplication by $10^{4}$. They include TCA-soluble ${ }^{14} \mathrm{C}$ metabolites of phenylalanine which, however, were not analysed.

Percentage values are based on the total radioactivity of the suspension or fraction and are the means \pm S.E.M. of four experiments.

- Ten cerebral cortices of 18-day-old rats were chopped with a razor blade and passed through the 33.3, 110 and $73 \mu \mathrm{m}$ nylon meshes as described in Methods. The weight of a single cortex was $0.67 \mathrm{~g}$.

TABLe 9,-The Effect of AGE ON THE TCA-SOLUble RAdioACtivity

\begin{tabular}{|c|c|c|c|c|}
\hline Fraction & $\begin{array}{c}5 \text { days }(n=2) \\
(\%)\end{array}$ & $\begin{array}{c}10 \text { days }(\mathrm{n}=3) \\
(\%)\end{array}$ & $\begin{array}{c}18 \text { days }(n=4) \\
(\%)\end{array}$ & $\begin{array}{c}43 \text { days }(n=3) \\
(\%)\end{array}$ \\
\hline Cortex suspension* & $\begin{array}{c}91 \cdot 1 \\
(90 \cdot 0,92 \cdot 1)\end{array}$ & $87.5 \pm 0.23$ & $79 \cdot 1 \pm 4 \cdot 00$ & $84 \cdot 1 \pm 1 \cdot 31$ \\
\hline Neuronal perikarya & $\begin{array}{c}44 \cdot 5 \\
(43 \cdot 0,45 \cdot 9)\end{array}$ & $49 \cdot 0 \pm 8 \cdot 42$ & $58 \cdot 5 \pm 4 \cdot 10$ & $75 \cdot 2 \pm 2 \cdot 42$ \\
\hline Neuronal cell sap & $\begin{array}{c}46 \cdot 7 \\
(44 \cdot 1,49 \cdot 2)\end{array}$ & $53.7 \pm 8.60$ & $79.9 \pm 7 \cdot 59$ & $100 \pm 0.00$ \\
\hline
\end{tabular}

The preparations were prepared as described in Methods. The in vivo pulse time with $\mathrm{L}-\left[{ }^{14} \mathrm{C}\right]-$ phenylalanine was $10 \mathrm{~min}$. The TCA-soluble activity was as defined in Table 8.

Except where individual values are given ( 5 days), values are expressed as per cent of the total radioactivity of the suspension of fraction \pm S.E.M.

* Ten cerebral cortices were chopped with a razor blade and passed through 333,110 and $73 \mu \mathrm{m}$ nylon meshes as described in Methods.

\section{DISCUSSION}

Our cell separation procedure (SELLINGER et al., 1971) makes possible the preparation of mutually uncontaminated fractions of neuronal perikarya and glial cells. As isolated, the neuronal perikarya are shorn of most processes (Fig. 1A), but their nuclei and nucleoli are clearly outlined and their cytoplasm appears richly organized 
(Fig. 1B). Electron microscopy of the neuronal perikarya (Fig. 2, A and B) and of the glial cells (Fig. 2D) revealed largely, if not entirely, intact plasma membranes, rather well-preserved intracellular organelles and a normal double-layered nuclear envelope. Our fraction of glial cells (Fig. 1C) most closely compares with the preparation described by NorTON and PODUSLo (1970), since the numerous processes appeared preserved and the nucleus comprised the major portion of the cellular space. With our technique, the yield (on the basis of protein) of both cell types, but particularly that of the neuronal perikarya, decreased with age, a feature previously not noted by most of the other authors who have applied similar cell-separation techniques at only one age (Rose, 1967; Flangas and Bowman, 1968; Blomstrand and Hamberger, 1969). Nor TON and PoDusLo (1970), who worked with 10-30-day-old rats, reported an approximately five-fold higher yield of neuronal perikarya than of glial cells (NP/G: 5). Our NP/G ratios (Table 1) for the same age span ranged from a high value of 164 at 10 days to a low value of 17.4 at 43 days. We cannot assess whether this agedependent decrease in the relative yield of cells is a consequence of the technical arbitrariness of imposing a constant pore-size limit to the passage of cells derived from cortices of varying age or whether, instead, it is the result of developmental changes in the physical state and/or the cellular and hence chemical composition of the brain cortex (CALEY and MAXwell, 1968a, $b$ ). The high initial NP/G ratio (Table 1; 5 days) and the pronounced drop of this ratio within 1 week suggests that, as the number of glial cells increased in relation to the number of existing neurons to reach a constant density in presumably less than 23 days (DALTON, Hommes and LeBLOND, 1968), the isolation of neuronal perikarya became relatively more difficult than at very early post-natal times when neurons relatively process-free (CALEY and MAXWELL, 1968a) are known to predominate numerically (BRIZZEE et al., 1964).

The incorporation rates in vivo of labelled amino acids into cerebral proteins are known to be faster in young animals than in adults, with the major decrease in rate occurring soon after birth and followed subsequently by a lesser and more gradual decline (ABDEL-LATIF and ABOOD, 1966; SCHAIN et al., 1967; OjA, 1967). The results of studies in vitro generally support this conclusion (MURTHY and RAPPOPORT, 1965; MURTHY, 1966, 1970; JOHNSON and BELYTSCHKo, 1969; LERNER and JoHNSON, 1970; ROBERTs et al., 1970). Although our results on neuronal and glial protein synthesis in vivo confirm previous findings obtained for intact brain, they also bring out qualitative and quantitative differences between the two cell types. Thus, in the neuronal perikarya the specific radioactivity of the ${ }^{14} \mathrm{C}$-labelled proteins in the 43 -day-old rat was $1 / 7$ of that of the ${ }^{14} \mathrm{C}$-labelled proteins in the 5 - or 10 -day-old animal (Table 3 ), whereas the 43-day values were merely one-half of the 10-day values in the glial cells (Table 3). Furthermore, although the specific radioactivity of the glial ${ }^{14} \mathrm{C}$-labelled proteins increased perceptibly between days 10 and 18, namely, at a time of maximal synthesis of myelin by the oligodendrocytes, the specific radioactivity of the neuronal ${ }^{14} \mathrm{C}$-labelled proteins maintained a steady decline from its highest 5-day value to its lowest 43-day value. BLOMSTRAND and HAMBERGER (1969) noted that $1.5 \mathrm{~h}$ after the intravenous administration of $\left[{ }^{3} \mathrm{H}\right]$ leucine to adult rabbits, the neuronal proteins were 1.5- to 3-fold more highly labelled than the glial proteins and that this difference persisted up to $72 \mathrm{~h}$ post-administration. Quite to the contrary, our experiments (Fig. 3) indicate that in the cerebral cortex of the 18-day-old rat the glial proteins were more highly labelled at $5 \mathrm{~min}$ and again from $20 \mathrm{~min}$ onward, after a single injection of 
$\left[{ }^{14} \mathrm{C}\right]$ phenylalanine. Only at $10 \mathrm{~min}$ were the neuronal proteins more highly labelled than the glial proteins. This biphasic labelling pattern of the glial proteins (Fig. 3) may indicate a sequential and specific involvement of the astrocytes and the oligodendrocytes, there being no microglia in the 18-day-old cortex of the rat (CALEY and MAXWELL, 1968b).

The labelling of the suspension of cerebral cortex (Fig. 3) which still contained the majority of the fibres with their nerve endings, proceeded apparently more slowly than that of either cell type, presumably because fibres and particularly nerve endings were labelled only secondarily, i.e. as a result of the transport of labelled perikaryal proteins into and down the axon and eventually into the endings. Direct evidence in support of this interpretation was obtained when we noted that the proteins of the fraction of nerve fibres and endings which is collected early in the isolation procedure (from the $1.0 \mathrm{M}-1.75 \mathrm{M}$-sucrose interface; see Methods) were most highly labelled 20 min after the administration of $\mathrm{L}-\left[{ }^{14} \mathrm{C}\right]$ phenylalanine in contrast to the fraction of neuronal perikarya which was maximally labelled as early as $10 \mathrm{~min}$ after injection of label (Fig. 3). The study of the time-course of incorporation of $\mathrm{L}-\left[{ }^{14} \mathrm{C}\right]$ phenylalanine into proteins of the subcellular fractions of the neuronal perikarya of the 18-day-old cerebral cortex revealed a relatively sustained 19-21 per cent and 8-9 per cent, respectively, of the total radioactivity in the nuclear and cell sap fractions. The partition of the radioactivity between the mitochondrial and the microsomal fractions shifted from an equal distribution of 35-37 per cent in each at 5 and $10 \mathrm{~min}$ to a $2: 1$ proportion of 50.6 per cent vs. $25 \cdot 2$ per cent in favour of the mitochondrial fraction at $20 \mathrm{~min}$ (Table 6). The progressively higher radioactivity of the mitochondrial fraction becomes even more evident by comparing the specific radioactivities of the ${ }^{14} \mathrm{C}$-labelled proteins in the two fractions. Thus, the higher values in the microsomal fraction at 5 and $10 \mathrm{~min}$ (Fig. 4) shifted to the mitochondrial fraction by $20 \mathrm{~min}$. Interestingly, the specific radioactivity of all fractions except the soluble cell sap was virtually the same at $45 \mathrm{~min}$. Such results emphasize the remarkably rapid synthetic response of the 18-day-old neuron and illustrate the high capacity of neuronal ribosomes to carry out the process.

A comparison of the incorporation of $\mathrm{L}-\left[{ }^{14} \mathrm{C}\right]$ phenylalanine into the proteins of the subcellular fractions of the neuronal perikarya as a function of age also revealed significant differences (Fig. 5, Table 7). These differences were particularly noticeable in the mitochondrial fraction which contained 12.9 per cent of the radioactivity at 5 days, compared to 45.8 per cent at 43 days (Table 7). Interestingly, the protein in this fraction (Table 4 ) increased by only 50 per cent (from $14 \cdot 7$ per cent to 21.3 per cent), a finding suggesting that the more than 300 per cent increase in the mitochondrial radioactivity (Table 7) reflects a true, age-dependent enhancement of the rate of synthesis of presumably essential, structural mitochondrial proteins. The opposite situation prevailed in the microsomal fraction which lost one-half of its protein between days 5 and 43 (from 18.6 per cent to 9.2 per cent; Table 4 ) while losing only about one-third of its share of the total neuronal radioactivity (from 46.0 per cent to 31.0 per cent; Table 7). MURTHY and RAPPOPORT (1965) also observed a decrease in microsomal protein of rat brain that amounted to about 75 per cent between neonatal and adult animals. The results suggest a peak in the rate of synthesis of microsomal structures such as the membranes of the endoplasmic reticulum and the ribosomes before the animals are 5 days old and subsequently a very rapid decrease to much lower levels. Some evidence in support of this suggestion is provided by the finding that the greatest 
drop in specific radioactivity between days 5 and 43 was for the proteins in the microsomal fraction (Fig. 5). The reduction of protein synthesis in the microsomal fraction may reflect a decrease in the number of active polysomes which combine mRNA. MURTHY (1966) and, more recently, YAMAGAMI and MoRI (1970) have shown that polysomal preparations from adult rat brains contained significantly fewer heavy components than the corresponding polysomes from immature brain. Although the soluble neuronal proteins were moderately labelled within $10 \mathrm{~min}$ in the 5-day-old rat, they remained totally unlabelled in the 43-day-old animal presumably because rapid synthesis of soluble perikaryal proteins ceased by about 20 days (DUTTON and Barondes, 1969; Johnson, Santiago and Sellinger, unpublished). The finding that the specific radioactivity of the soluble ${ }^{14} \mathrm{C}$-labelled proteins decreased to zero by 43 days (Table 7) would seem to indicate the formation of proteins with increasingly slower rates of turnover with age. This finding provides direct confirmation of the results of LAJTHA et al. (1957) and LAJTHA $(1964 a, b)$ who found that the average halflife of cerebral proteins in the rat increased with age as a result of the formation in the older brains of proteins with proportionately slower rates of turnover than those found in the immature brain.

Although the present experiments reveal differences in protein synthesis between neuronal and glial cells that we have tried to relate to parameters possibly governing the independent maturation of each cell type, the results were obtained admittedly from only one brain region, namely the cerebral cortex. As FISH and WINICK (1969) have recently stated, however, there exist in brain 'distinct regional patterns of cellular growth during postnatal development', and these must be considered before generalizations are warranted. Moreover, in agreement with BASs, NETSKY and YouNG (1969), we fully realize that the biochemical 'maturation of the rat cerebrum is a complex process involving many stages of cellular migration and differentiation that are both critical and interdependent', and thus that our approach only opens the door to future investigations of this highly complex phenomenon.

Acknowledgements-We thank Dr. V. Idoyaga-VARgas and Mrs. Patricia D. PeTteT for assistance in electron microscopy. Appreciation is expressed to Mr. WAYNE G. OHLSsON for his invaluable technical assistance.

\section{REFERENCES}

Amdel-Latif A. A. and Abood L. G. (1966) J. Neurochem. 13, 1189.

AdAMS D. H. and LiM L. (1966) Biochem. J. 99, 261.

Barondes S. H. (1964) J. Neurochem. 11, 663.

Bass N. H., Netsky M. G. and Young E. (1969) Neurology, Minneap. 19, 258.

Blomstrand C. and Hamberger A. (1969) J. Neurochem. 16, 1401.

Bondy S. C. and Roberts S. (1968) Biochem. J. 109, 533.

BRIZZEE K. R., VOGT J. and KHARETCHKo X. (1964) In Growth and Maturation of the Brain (Edited by

Pur pura D. P. and SchadE J. P.) Progress in Brain Research, vol. 4, p. 136. Elsevier, Amsterdam.

Caley D. W. and MaXwell D. S. (1968a) J. comp. Neurol. 133, 17.

Caley D. W. and MaXwell D. S. (1968b) J. comp. Neurol. 133, 45.

Dalton M. M., Hommes O. R. and Leblond C. P. (1968) J. comp. Neurol. 134, 397.

Dutton G. R. and Barondes S. (1969) Science, N.Y. 166, 1637.

Fish I. and WinICK M. (1969) Pediat. Res. 3, 407.

Flangas A. L. and Bowman R. E. (1968) Science, N.Y. 161, 1025.

Fleck A. and BEGG P. (1965) Biochim. biophys. Acta 108, 333.

Freysz L., Bieth R., Judes C., Sensenbrenner M., Jacob M. and Mandel P. (1968) J. Neurochem 15, 307.

Friedman H. P. and Wenger B. S. (1970) J. Embryol. exp. Morph. 23, 289.

Gaitonde M. K. and Richter D. (1956) Proc. R. Soc. 145, 83. 
Herriman I. D. and HUNTER G. D. (1965) J. Neurochem. 12, 937.

JoHNSON T. C. (1967) J. Neurochem. 14, 1075.

JoHnson T. C. (1968) J. Neurochem. 15, 1189.

Johnson T. C. and Belytschko G. (1969) Proc. natn. Acad. Sci. U.S.A. 62, 844.

Johnson T. C. and LutTGES M. W. (1966) J. Neurochem. 13, 545.

Johnson D. E. and Sellinger O. Z. (1970) J. Cell Biol. 47, 100a.

LAHIRI S. and LaJtha A. (1964) J. Neurochem. 11, 77.

LAJTHA A. (1964a) Int. Rev. Neurobiol. 6, 1.

Lajtha A. (1964b) Int. Rev. Neurobiol. 7, 1.

Lajtha A., Furst A., Gerstein A. and Waelsch H. (1957) J. Neurochem. 1, 289.

Lerner M. P. and Johnson T. C. (1970) J. biol. Chem. 245, 1388.

Lowry O. H., Rosebrough W. J., FarR A. L. and Randall R. J. (1951) J. biol. Chem. 193, 265.

Muller S. A. (1969) In Mammalian Protein Metabolism (Edited by Munro H. N.) Vol. 3, p. 200. Academic Press, New York.

Moore B. W., Perez V. J. and Gehring M. (1968) J. Neurochem. 15, 265.

MURTHY M. R. V. (1966) Biochim. biophys. Acta 119, 599.

Murthy M. R. V. (1970) In Protein Metabolism of the Nervous System (Edited by LAJTha A.) p. 109. Plenum Press, New York.

MURTHY M. R. V. and RAPPOPORT D. A. (1965) Biochim. biophys. Acta 95, 121.

Norton W. T. and Poduslo S. E. (1970) Science, N.Y. 167, 1144.

OjA S. S. (1967) Ann. Acad. Sci. Fenn. 131, 1.

Roberts S., Zomzely C. E. and Bondy S. C. (1970) In Protein Metabolism of the Nervous System (Edited by Lajtha A.) p. 3. Plenum Press, New York.

Rose S. P. R. (1967) Biochem. J. 102, 33.

Rose S. P. R. and Sinha A. K. (1969) J. Neurochem. 16, 1319.

SATAKE M. and ABE S. (1966) J. Biochem., Tokyo 59, 72.

Satake M., Hasegawa S., Abe S. and Tanaka R. (1968) Brain Res. 11, 246.

Schain R. J., Carver M. J., Copenhaver J. H. and Underdahl W. R. (1967) Science, N. Y. $156,984$.

Sellinger O. Z. and Azcurra J. M. (1970) Trans. Am. Soc. Neurochem. 1, 22.

Sellinger O. Z., Azcurra J. M., Johnson D. E., Ohlsson W. G. and Lodin Z. (1971) Nature, Lond. $230,253$.

TUOMEY S. L. and WyTtenbach C. R. (1970) Trans. Am. Soc. Neurochem. 1, 73.

YAMAGAMI S., Fritz R. R. and RAPPOPORT D. A. (1966) Biochem. biophys. Acta 129, 532.

YAMAGAMI S. and MORI K. (1970) J. Neurochem. 17, 721.

Zomzely C. E., Roberts S., Gruber C. P. and Brown D. M. (1968) J. biol. Chem. 243, 5396. 